\title{
The move to preserve therapeutic cloning
}

In mid-October 2003, on the eve of the annual meeting of the American Society for Reproductive Medicine (ASRM) in Texas, the Cypriot-born physician Panayiotis Zavos held a press conference to announce that he had frozen a cloned human embryo at the 10-cell stage and was preparing to implant it in a woman. As with his previous claims, Zavos offered no scientific data to support his work. Nonetheless, there is fresh concern within the research community that such outlandish remarks are fueling political efforts to ban

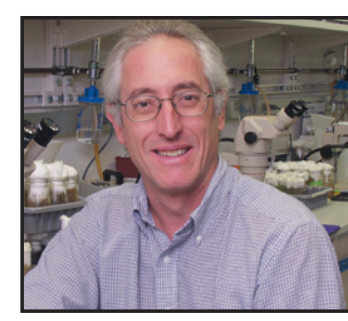

Larry Goldstein: time to act

\section{UN convention impasse}

What worries researchers is the nature of current political efforts to ban human cloning. On November 6th, an ad hoc Working Group of the United Nations, convened two years earlier, decided by only 80 votes to 79 to delay discussion of an agreement on an international treaty banning human cloning for a further two years. The group has been split because 40 nations, led by Costa Rica, have demanded a ban on all forms of cloning, both reproductive and therapeutic. The latter technique can involve creating and then destroying human embryos.

Supporters of a total ban include several African and South American countries and, most notably, the United States, countries known for their strong religious factions and antiabortion views. Robert Lanza, vice president of Medical \& Scientific Development at Advanced Cell Technology, Worcester, Massachusetts, USA, told the JCI, "The Bush Administration is siding more with religious than scientific views. My feeling as a scientist is that the government should be looking out for the health and well-being of the population, not taking sides in religious debates because clearly there is a diversity of religious viewpoints."

Meanwhile, a group of 14 countries that includes the United Kingdom, China, and South Africa insists that the international treaty should apply to reproductive cloning only. They argue that, given the diversity of opin-

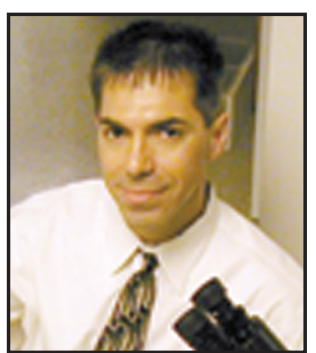

Bob Lanza: doubts Zavos' latest claim
"The UN is deadlocked," says Goldstein. "The extremists, led by the US, would like to ban cloning and all possible precursor technologies. Why don't they at least do what they agree on - ban human reproductive cloning? Those who would go further than the point everybody agrees upon block the simplest objective. I think that's inappropriate politically and ethically. I'm ashamed of my government."

\section{Mobilizing scientists}

Having been part of the debate for five years, Goldstein is now one of several scientists who feel so strongly about the issue that they have joined a new lobbying group, the Human Cloning Policy Institute (HCPI). The HCPI, which consists of 16 international scientists, lawyers, and human rights activists, has petitioned UN SecretaryGeneral Kofi Annan to take the matter to the International Court of Justice for resolution.

The HCPI was formed in the fall of 2003 by Bernie Segal, a Florida-based attorney who has sued the Raelian cult to demand that they produce the baby that they claim to have cloned (through Clonaid, their subsidiary) at the start of the year. "I serve as a member of HCPI's scientific advisory committee," Goldstein told the JCI. "I was approached by Bernie Segal, who I felt was doing the right thing, namely moving in legal and ethical ways to oppose an unethical medical practice - cloning a human being, but also trying to preserve the ability and legitimate need of the scientific and medical community to pursue the use of related technology; ion on the morality of therapeutic that is, generating viable pluripotent cloning and its potential to offer medical breakthroughs against certain diseases, individual countries should be allowed to regulate it as they see fit. stem cells for research and potential therapy. I felt that he'd do a better a better job with sound scientific advice, so I joined." 
In October, Australian reproductive biologist Alan Trounson, another member of the HCPI, publicly likened the risk of human cloning to that of the misuse of nuclear armaments. Given that most existing animal clones have health defects such as obesity and respiratory and immune problems, he said, children born from the technique could face death at any point in time, and that

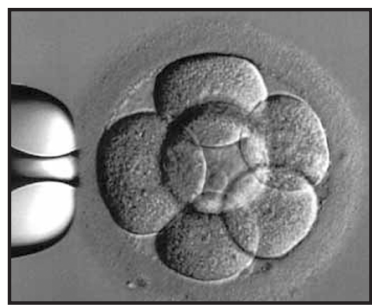

Human embryo at the tencell stage. sentation in the media and public hysteria to get in the way of legitimate scientific exchange," Tipton told the JCI. this was an unreasonable way to live.

Massey is also an HPCI member. "The reason $\mathrm{I}$ joined the panel is because I know there are people out there who would try to clone their loved ones or themselves if they thought they had a shot at it. They will continue to be tantalized by the promises of the fringe elements who take advantage of the press to promote awareness of their activities. Those who are making the claims, and have no science, need to be discredited. This is a goal of the HCPI, promote science, and discourage the hope for reproductive cloning."

Other scientific groups are also mobilizing. In September, more than 60 science academies from around the world, under the auspices of the InterAcademy Panel, petitioned the UN to adopt a ban on reproductive cloning while urging against making therapeutic cloning illegal.

However, such activity has not silenced the claims of proponents of human cloning. Zavos is becoming a familiar figure at reproductive biology meetings around the world. At the ASRM meeting, he presented data on nuclear transfer in cow embryos as a model for his human work. Perhaps, then, it is incumbent on societies to take a stance and not give rogue scientists a platform. ASRM spokesperson Sean Tipton disagrees. "The scientific community shouldn't allow misrepre-

\section{A question of time}

Tipton went on to explain ASRM's policy with regard to human cloning. "We would not let people present something that said 'here are the results of human cloning. Here's a baby.' But Dr. Zavos' work did not present an ethical obstacle. He didn't move anything any closer to what's happening in human cloning. We've taken a clear, scientific stance against that because the science hasn't progressed to a point where you can make an attempt at it safely. We haven't addressed the ultimate ethical question of should it ever happen. We're still examining that and our membership is torn on it. There are a lot of people who recognize that much of the debate around human cloning is very similar to that which surrounded the first in vitro fertilization. Until the scientific question is clear, we have not felt the need to take up the larger ethical question as yet."

That point may be a long way off. "First of all, I think it's highly unlikely that Zavos would have frozen it at the 10-cell unless it had stopped dividing, and if had, it wouldn't be viable," says Lanza, whose company has cloned around 100 cows. "Also, in all probability, 10 cells may not really be 10 cells but may be a fractionated embryo, i.e., cells have broken into smaller units. The human genome doesn't really kick in until the compacting morula stage, which is at least a 16-cell. And when it starts to compact there are certain genes that are turned on so that you would be able to visibly ensure that a clone has taken over and that it's viable."

Moreover, credible cloning researchers are currently debating whether primate embryos can ever undergo successful nuclear transfer, since meiotic spindle removal from recipient oocytes, which occurs during enucleation, appears to prevent embryo reconstitution (2). Although others believe it's simply a numbers game, Mark Westhusin, a member of the Texas A \& M University team that cloned the first cat, told the JCI, "The nuclear transfer procedure is not the obstacle. The biggest issue is logistics. It's very inefficient in any species, so where are you going to get 100 eggs on any given day that are competent and can reprogram a nucleus, and where are you going to get enough surrogate mothers, let alone a research team willing to be a part of this?"

Thus, despite the UN's wranglings, it still seems that time is on their side

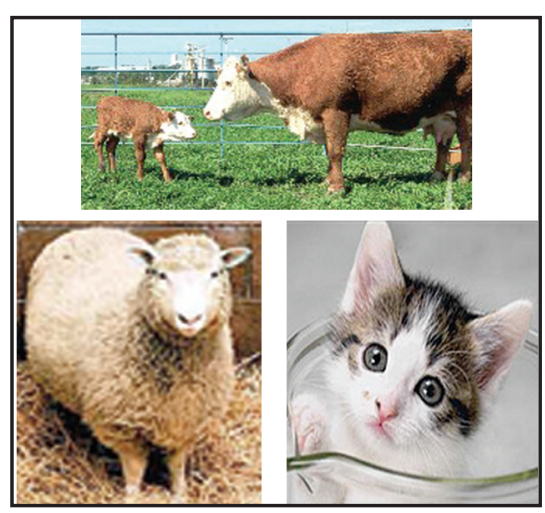

Cloned cows, sheep, and cats. Are humans next?

in their attempt to introduce an international cloning law that will please the majority. But Joe Massey's words should serve as a strong incentive to act sooner rather than later: "If 100 scientists learned to clone human cells, only one would be needed to blow the lid off the science and take it to reproduction."

\footnotetext{
1. Tamashiro, K.L., et al. 2002. Cloned mice have an obese phenotype not transmitted to their off spring. Nature Med. 8:262-267.

2. Simerly, C., et al. 2003. Molecular correlates of primate nuclear transfer failures. Science. 300:297.
}

Karen Birmingham, London, United Kingdom 